Jerzy SZYPUEA

\title{
AN ATTEMPT TO USE VARIOUS MATHEMATICAL MODELS TO EXTRAPOLATE FISH GROWTH RATE BEYOND THE RANGE OF EMPIRICAL DATA
}

\section{PRÓBA ZASTOSOWANIA RÓŻNYCH MODELI MATEMATYCZNYCH DO EKSTRAPOLACJI TEMPA WZROSTU DLUGOSCI RYB POZA ZAKRES DANYCH EMPIRYCZNYCH}

\author{
INSTITUTE OF ICHTHYOLOGY, \\ SZCZECIN
}

\begin{abstract}
The paper presents data on possibilities to extrapolate results obtained when extending four most commonly used length growth mathematical models (the binomial, von Bertalanffy equation, Gompertz equation, and Ford-Walford model) beyond the range of empirical data. The technique used involved calculating a model from a part of empirical data only and comparing the extrapolated results obtained with the rest of the empirical data. The extrapolated results were deemed accurate enough if a difference betweer then and the corresponding empirical values did not exceed $5 \%$.
\end{abstract}

\section{INTRODUCTION}

The aim of the present paper was to check a possibility to extrapolate (beyond the range of empirical data) results on fish length growth rate obtained with the commonly used mathematical growth models. Should such a possibility be confirmed, it would be of importance in relatively frequent cases when data on late years of fish life are poorly represented due to low abundances, or when data on fish length in early years are unreliable due to the initial annual rings being poorly legible.

If a possibility to extrapolate length growth data is confirmed, then it also would be possible to extrapolate fish weight growth. The mathematical weight growth models most 
useful for the purpose are the modified von Bertalanffy equation and the $3 \mathrm{rd}$ order polynomial (Szypuła, 1980), closely related to the corresponding length growth models (the von Bertalanffy equation and the binomial) which are, among others, analysed in the present work.

\section{MATERIALS AND METHODS}

The basic materials comprised data on length growth rate of 50 fish species, published by Anon. (1949), Cięglewicz and Draganik (1969), Krzykawski (1976), Nikolski (1956), and Svetovidov (1964). The species studied are both marine and freshwater, their respective growths proceeding very differently; the length of time for which growth rates were calculated differed among the species as well (from 6 to 16 years).

Four mathematical length growth models: the binomial, von Bertalanffy equation, Gompertz equation, and Ford-Walford formula were tested. Parameters of the first three equations were determined in the identical way for both directions of extrapolation ("forward", i.e., when theoretical lengths in later years are calculated from lengths attained in earlier years, and "backward", when the reverse situation occurred). The Ford-Walford equation had to be transformed in order to perform a backward extrapolation. As commonly known, the equation in its simplified form is as follows:

$$
=1_{1}+k 1_{t-1}
$$

When extrapolating backward, the above equation has to be transformed such that a length in a year preceeding the given one (i.e., when $1_{t}$ is given, $1_{t-1}$ has to be calculated) can be computed. The transformed Ford-Walford equation used in backward extrapolation has the form of

$$
1_{t-1}=\frac{1_{t}-1}{k}
$$

The values of $1_{1}$ and $k$ are calculated according to the generally used method: $l_{t}$ is the empirical length in a year which is the lower limit of the data range on hand (for example, if the model is calculated from year 10,11 , and $12,1_{10}$ should be regarded as 1 ). Having considered the $1_{t}$ value in the above equation and calculated $1_{t-1}$, the latter length is then treated as $1_{t}$ and the next theoretical length $1_{t-1}$ calculated.

To check if extrapolation is possible, mathematical growth models were calculated from a part of empirical data only and then the calculated (extrapolated) results were compared with the remaining empirical data. For example, when data on 6 years were available, a model was applied to the data on the first three years and results for the remaining years were calculated from the model; then the calculated results were compared with the empirical data on year 4,5 , and 6 . As stated above, a possibility and range of extrapolation in both directions had to be tested; the backward extrapolation 
involved empirical data on late years of life and the calculated results for the early years were compared with empirical data for these years.

The following parameters, denoted by appropriate symbols, were used when describing methods and compiling results:

$$
\begin{aligned}
& Z_{E}=\text { range of empirical data, } \\
& Z_{M}=\text { range of empirical data used to calculate a model, } \\
& Z_{0.05}=\text { extrapolation range, } \\
& Z_{W}=\frac{Z_{0.05} 100}{Z_{M}}=\text { relative extrapolation range. }
\end{aligned}
$$

Additionally, $\rightarrow$ and $\leftarrow$ were used to denote forward and backward extrapolations, respectively. If, for example, empirical data on hand covered 10 years of fish life and the forward extrapolation range was 5 years, the case was described in the following way:

$$
\mathbb{Z}_{E}=10 ; \mathbb{Z}_{M}=4 ; \rightarrow \mathbb{Z}_{0.05}=5 ; \text { and } \longrightarrow \mathbb{Z}_{W}=125 \%
$$

The extrapolated model data were considered accurate enough if a difference between a calculated and empirical length did not exceed $5 \%$ of the latter. To accurately determine the extrapolation range beyond $\mathbb{Z}_{M}$, two subsequent years of life were selected such that the difference mentioned was lower than $5 \%$ in the first and higher in the second (all the cases tested revealed that, if the difference was higher than $5 \%$ for a given year, a further extrapolation resulted in differences greated than $5 \%$ as well, the differences usually increasing noticeably); the range within which the difference amounted to precisely $5 \%$ was found by interpolation.

As checking if the extrapolation range depends on the data range used in mathematical growth models $\left(\mathbb{Z}_{M}\right)$ was one of important issues emerging when testing possibilities of extrapolation, several models on different sets of data each were calculated for every species. Thus, for the species whose growth was described over 6 years of life, 2 versions of each model were calculated (based on data for 3 and 4 years). With increasing range of the empirical data $\left(\mathbb{Z}_{\mathbb{E}}\right)$, the number of growth models calculated was increased as well; 10 versions of each model (for $\mathbb{Z}_{\mathrm{M}}$ from 3 to 12 years) were calculated in the case of Acipenser stellatus for which growth data on 16 years were available, that is a total of 40 growth equations were determined in forward extrapolation. Generally, when testing the forward extrapolation, a total of 926 growth equations were determined for the 50 species analysed, 798 equations being determined in backward extrapolation. Table 1 lists the species analysed, ranges of empirical data, and number of growth models calculated for each species.

Calculating a growth model was, as a rule, started for a 3-yr (initial or terminal) range. However, it was necessary in some cases to first calculate models for 4 , or even 5 , years (even 8 years in backward extrapolation) because a lower $\mathbb{Z}_{\mathrm{M}}$ failed to show decreasing length increments in subsequent years of life, which is a condition necessary to calculate 


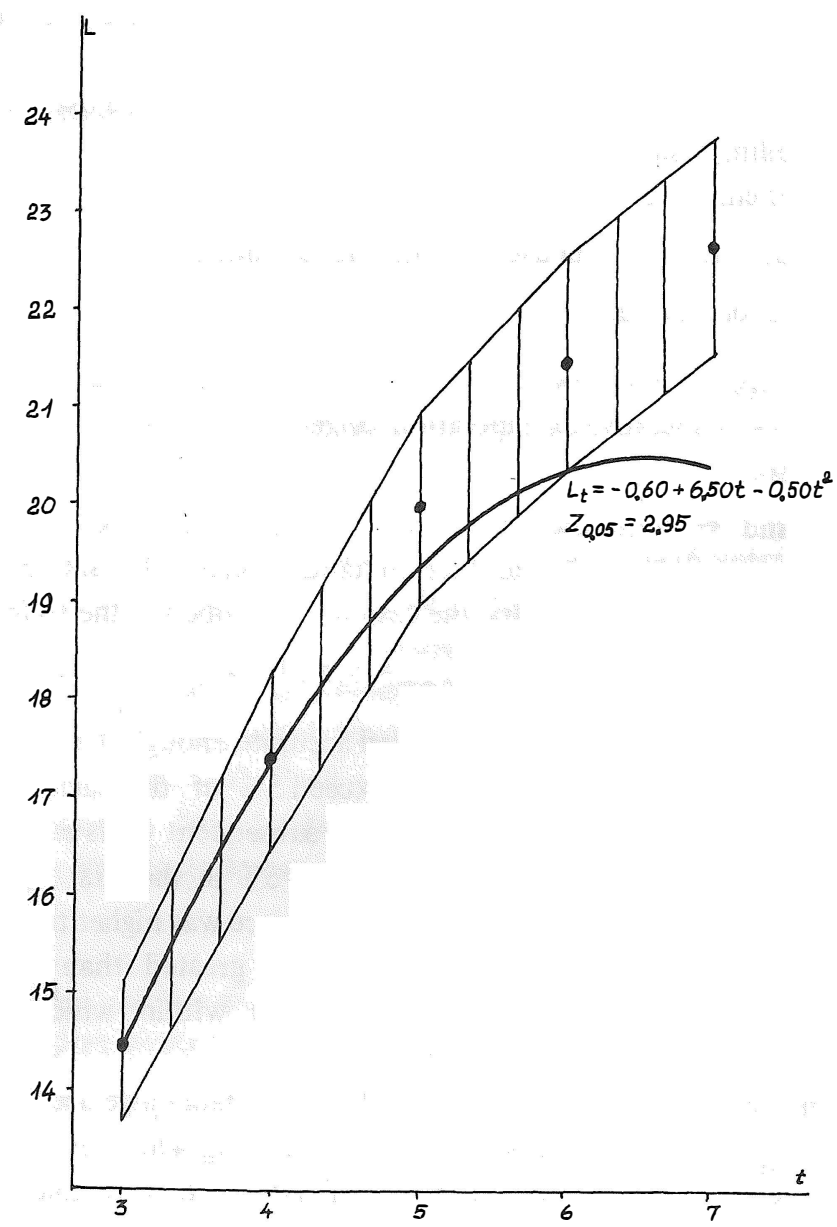

Fig. 1. Forward extrapolation of length growth in Leuciscus waleckii with the binomial (points denote empirical data; hatched area represents $5 \%$ tolerance range)

$$
\mathrm{Z}_{\mathrm{E}}=7 ; \mathrm{Z}_{\mathrm{M}}=3 ; \mathrm{Z}_{0.05}=2.95
$$

parameters of the growth models adopted. The result of such a state of affairs is discrepancies, seen in Table 1 between numberd of models calculated in forward and backward extrapolation.

Figs 1 and 2 show the situations occurring most frequently when extrapolating model data in both directions. Empirical data used, covering 7 years, concern Leuciscus waleckii from the Lake Orel. The model applied (the binomial) was calculated for the first (Fig. 1) and terminal (Fig. 2) 3 years of life. As seen from the figures, the forward extrapolation was possible over a range much longer than in the backward extrapolation $\left(\rightarrow Z_{0.05}\right.$ $\left.=2.95 \mathrm{yr} ; \leftarrow \mathrm{Z}_{0.05}=1.06 \mathrm{yr}\right)$ 


\section{RESULTS}

The first stage of calculations involved determining the range of extrapolation relative to the empirical range available for a given species. The discrimination is necessary because, without it, the results would not be fully comparable (for a species whose empirical data range covered 6 years, a model calculated from 3 years allows to compare extrapolated and empirical data for the next 3 years; on the other hand, if the empirical range covers 16 years, extrapolation from a model calculated for 3 years and comparison with empirical data would be theoretically possible for the next 13 years; obviously, the two cases cannot have the same meaning).

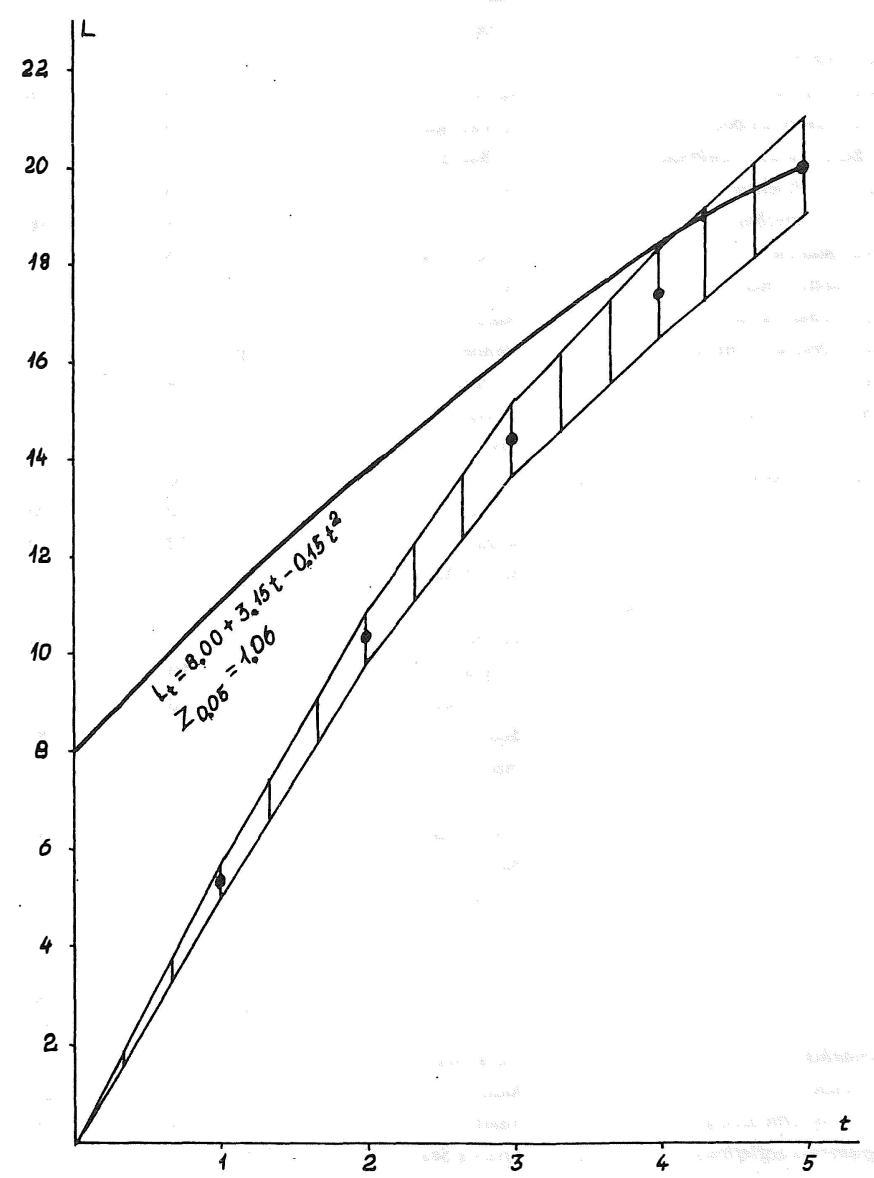

Fig. 2. Backward extrapolation of length growth in Leuciscus waleckii with the binomial (points and hatched area as in Fig. 1)

$$
\mathrm{Z}_{\mathrm{E}}=7 ; \mathrm{Z}_{\mathrm{M}}=3 ; \mathrm{z}_{0.05}=1.06
$$


Fish species for which growth models were analysed and number of growth models in forward $(\rightarrow n)$ and backward $(\leftarrow n)$ extrapolation

\begin{tabular}{|c|c|c|c|c|c|}
\hline No. & Species & Area & $\mathrm{z}_{\mathrm{E}}$ & $\rightarrow \mathrm{n}$ & $\leftarrow \mathrm{n}$ \\
\hline 1. & Sardinops sagax & Zaliv Petra Velikogo & 6 & 8 & 8 \\
\hline 2. & Caspialosa saposhnikovi & Caspian Sea & 6 & 8 & 8 \\
\hline 3. & Clupea harengus & Atlantic Sea & 6 & 8 & 8 \\
\hline 4. & Oncorhynchus keta & Amur & 6 & 8 & 8 \\
\hline 5. & Pelecus cultratus & Don & 6 & 8 & 8 \\
\hline 6. & Callionymus lyra & Black Sea & 6 & 8 & 8 \\
\hline 7. & Scorpaena paorcus & Black Sea & 6 & 4 & 8 \\
\hline 8. & Plagiognathops microlepis & Amur & 6 & 8 & 8 \\
\hline 9. & Culter alburnus & Amur & 6 & 8 & 8 \\
\hline 10. & Aspius aspius & Volga & .7 & 12 & 12 \\
\hline 11. & Leuciscus waleckii & Orel & 7 & 12 & 12 \\
\hline 12. & Leuciscus schmidti & L. Issyk Kul & 8 & 16 & 16 \\
\hline 13. & Coregonus lavaretus baeri & L. Ladoga & 8 & 16 & 16 \\
\hline 14. & Thymallus arcticus baicalensis & L. Baikal & 8 & 16 & 12 \\
\hline 15. & Parabramis peiknensis & Amur & 8 & 16 & 12 \\
\hline 16. & Elopichthys bamubsa & Amur & 8 & 16 & 16 \\
\hline 17. & Siniperca chua-tsi & L. Khanka & 8 & 16 & 4 \\
\hline 18. & Ophiocephahus argus & Amur & 8 & 16 & 12 \\
\hline 19. & Hemibarbus maculatus & Amur & 8 & 16 & 16 \\
\hline 20. & Osmerus eperlanus dentex & Yenisey & 9 & 16 & 12 \\
\hline 21. & Lucioperca lucioperca & L. Imen & 9 & 12 & 16 \\
\hline 22. & Brachymystax lenok & Onon & 9 & 16 & 12 \\
\hline 23. & Merluccius merluccüus & Black Sea & 10 & 18 & 16 \\
\hline 24. & Liocassis ussuriensis & Amur & 10 & 20 & - \\
\hline 25. & Hemibarbus labeo & Amur & 10 & 20 & 20 \\
\hline 26. & Acipenser mudiventris & Kura & 10 & 20 & 18 \\
\hline 27. & Acipenser güldenstädti & Sea of Azov & 10 & 20 & 12 \\
\hline 28. & Coregonus autumnalis migratorius & L. Baikal & 10 & 20 & 17 \\
\hline 29. & Coregonus lavaretus widegreni & L. Onega & 10 & 20 & 20 \\
\hline 30. & Lucioperca marina & Caspian Sea & 10 & 20 & 16 \\
\hline 31. & Thunnus thynnus & Japan Sea & 10 & 20 & 12 \\
\hline 32. & Mugil auratus & Black Sea & 10 & 20 & 20 \\
\hline 33. & Trahcurus mediterraneus ponticus & Black Sea & 11 & 20 & 24 \\
\hline 34. & Erythroculter erythropterus & L. Udyl & 11 & 24 & 24 \\
\hline 35. & Mylopharyngodon piceus & Slavyanka & 11 & 20 & 24 \\
\hline 36. & Clupea harengus pallasi & Barents Sea & 11 & 16 & 24 \\
\hline 37. & Perca fluviatilis & L. Ladoga & 11 & 20 & 24 \\
\hline 38. & Pollachius virens & Norwegian Sea & 12 & 24 & 22 \\
\hline 39. & Cyprinus carpio & Amur & 12 & 24 & 24 \\
\hline 40. & Leuciscus idus & Volga & 12 & 24 & 14 \\
\hline 41. & Abramis brame & Volga & 12 & 20 & 24 \\
\hline 42. & Mugil cephahus & Black Sea & 12 & 24 & 24 \\
\hline 43. & Hucho taimen & Amur & 13 & 24 & 24 \\
\hline 44. & Ctenopharyngodon idella & Amur & 13 & 28 & 28 \\
\hline 45. & Melanogrammus aeglefinus & Barents Sea & 13 & 28 & 26 \\
\hline 46. & Huso huso & Black Sea & 14 & 32 & 4 \\
\hline 47. & Coregonus lavaretus baicalensis & L. Baikal & 15 & 36 & 16 \\
\hline 48. & Atheresthes evermanni & Bering Sea & 15 & 36 & 33 \\
\hline 49. & Reinhardtüus hippoglossoides & Barents Sea & 15 & 24 & 30 \\
\hline 50. & Acipenser stellatus & Black Sea & 16 & 40 & 18 \\
\hline \multicolumn{4}{|c|}{ Total } & 926 & 798 \\
\hline
\end{tabular}


Mean extrapolation ranges $\left(Z_{0.05}\right)$ and mean relative extrapolation ranges $\left(Z_{\mathrm{W}}\right)$ presented in relation to the range of empirical data $\left(Z_{\mathrm{E}}\right)$ and mathematical growth model used $(\mathrm{A}=$ binomial $\mathrm{B}=$ von Bertalanffy equation; $\mathrm{C}=$ Gompert $\mathrm{z}$ equation; $\mathrm{D}=$ Ford-Walford model $)$

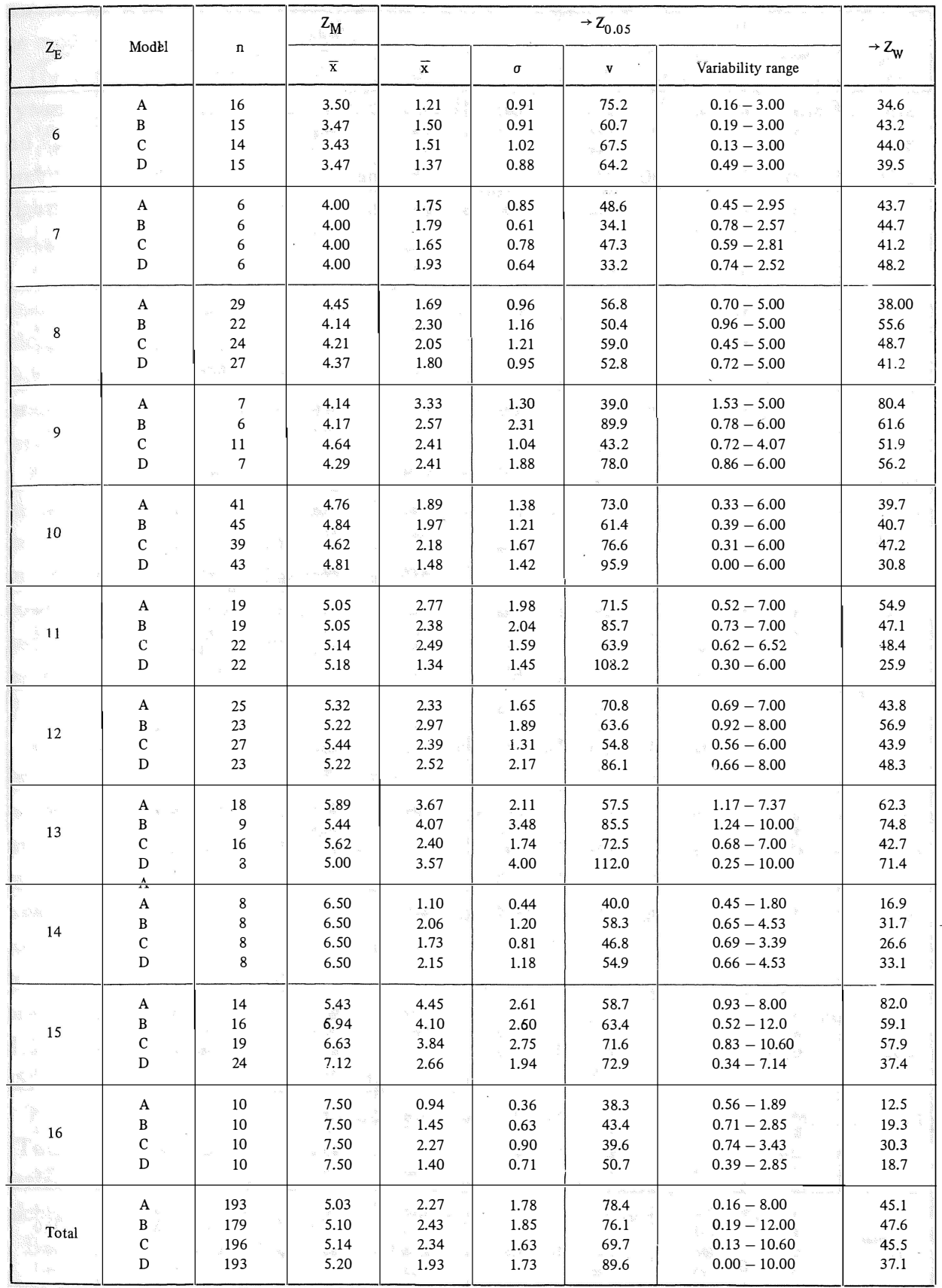


Mean extrapolation ranges $\left(\mathrm{Z}_{0.05}\right)$ and mean relative extrapolation ranges $\left(\mathrm{Z}_{\mathrm{W}}\right)$ presented in relation to the range of empirical data $\left(Z_{E}\right)$ and mathematical growth model used (A, B, C, and D as in Table 2)

\begin{tabular}{|c|c|c|c|c|c|c|c|c|}
\hline \multirow{2}{*}{$\mathrm{Z}_{\mathrm{E}}$} & \multirow{2}{*}{ Model } & \multirow{2}{*}{$\mathrm{n}$} & \multirow{2}{*}{$\frac{\mathrm{Z}_{\mathrm{M}}}{\bar{x}}$} & \multicolumn{4}{|c|}{$\rightarrow \mathrm{Z}_{0.05}$} & \multirow{2}{*}{$\leftarrow Z_{W}$} \\
\hline & & & & $\overline{\mathrm{x}}$ & $\sigma$ & v & Variability range & \\
\hline 6 & $\begin{array}{l}\text { A } \\
\text { B } \\
\text { C } \\
\text { D }\end{array}$ & $\begin{array}{l}16 \\
16 \\
16 \\
17\end{array}$ & $\begin{array}{l}3.44 \\
3.44 \\
3.44 \\
3.47\end{array}$ & $\begin{array}{l}1.03 \\
1.38 \\
1.07 \\
1.52\end{array}$ & $\begin{array}{l}0.70 \\
0.62 \\
0.62 \\
0.63\end{array}$ & $\begin{array}{l}68.0 \\
44.9 \\
57.9 \\
41.4\end{array}$ & $\begin{array}{l}0.16-2.64 \\
0.38-3.00 \\
0.19-2.15 \\
0.55-3.00\end{array}$ & $\begin{array}{l}29.9 \\
40.1 \\
31.1 \\
43.8\end{array}$ \\
\hline 7 & $\begin{array}{l}\text { A } \\
\text { B } \\
\text { C } \\
\text { D }\end{array}$ & $\begin{array}{l}6 \\
5 \\
6 \\
6\end{array}$ & $\begin{array}{l}4.00 \\
3.80 \\
4.00 \\
4.00\end{array}$ & $\begin{array}{l}1.00 \\
1.79 \\
0.80 \\
1.50\end{array}$ & $\begin{array}{l}0.56 \\
0.77 \\
0.44 \\
0.48\end{array}$ & $\begin{array}{l}56.0 \\
43.0 \\
55.0 \\
32.0\end{array}$ & $\begin{array}{l}0.24-1.84 \\
1.10-3.00 \\
0.26-1.38 \\
0.81-2.00\end{array}$ & $\begin{array}{l}25.0 \\
47.1 \\
20.0 \\
37.5\end{array}$ \\
\hline 8 & $\begin{array}{l}\text { A } \\
\text { B } \\
\text { C } \\
\text { D }\end{array}$ & $\begin{array}{l}26 \\
23 \\
26 \\
22\end{array}$ & $\begin{array}{l}4.73 \\
4.61 \\
4.73 \\
4.64\end{array}$ & $\begin{array}{l}1.62 \\
2.21 \\
1.33 \\
1.91\end{array}$ & $\begin{array}{l}1.11 \\
1.05 \\
0.70 \\
1.01\end{array}$ & $\begin{array}{l}68.5 \\
47.5 \\
52.6 \\
52.9\end{array}$ & $\begin{array}{l}0.42-4.11 \\
1.11-4.89 \\
0.35-3.48 \\
0.59-5.00\end{array}$ & $\begin{array}{l}34.2 \\
47.9 \\
28.1 \\
41.2\end{array}$ \\
\hline 9 & $\begin{array}{l}\text { A } \\
\text { B } \\
\text { C } \\
\text { D }\end{array}$ & $\begin{array}{r}10 \\
9 \\
10 \\
9\end{array}$ & $\begin{array}{l}4.80 \\
4.89 \\
4.80 \\
4.67\end{array}$ & $\begin{array}{l}2.09 \\
2.44 \\
1.78 \\
2.45\end{array}$ & $\begin{array}{l}1.12 \\
0.71 \\
0.80 \\
0.90\end{array}$ & $\begin{array}{l}53.6 \\
29.1 \\
44.9 \\
36.7\end{array}$ & $\begin{array}{l}0.65-3.94 \\
1.65-3.83 \\
0.78-3.00 \\
1.61-4.00\end{array}$ & $\begin{array}{l}43.5 \\
49.9 \\
37.1 \\
52.5\end{array}$ \\
\hline 10 & $\begin{array}{l}\text { A } \\
\text { B } \\
\text { C } \\
\text { D }\end{array}$ & $\begin{array}{l}39 \\
37 \\
34 \\
39\end{array}$ & $\begin{array}{l}5.26 \\
5.16 \\
5.47 \\
5.26\end{array}$ & $\begin{array}{l}1.48 \\
2.04 \\
1.74 \\
2.22\end{array}$ & $\begin{array}{l}0.94 \\
0.98 \\
0.96 \\
0.89\end{array}$ & $\begin{array}{l}63.5 \\
48.0 \\
55.2 \\
40.1\end{array}$ & $\begin{array}{l}0.31-4.30 \\
0.00-4.78 \\
0.49-4.04 \\
0.68-5.32\end{array}$ & $\begin{array}{l}28.1 \\
39.5 \\
31.8 \\
42.2\end{array}$ \\
\hline 11 & $\begin{array}{l}\text { A } \\
\text { B } \\
\text { C } \\
\text { D }\end{array}$ & $\begin{array}{l}30 \\
30 \\
30 \\
30\end{array}$ & $\begin{array}{l}5.50 \\
5.50 \\
5.50 \\
5.50\end{array}$ & $\begin{array}{l}1.78 \\
2.05 \\
1.74 \\
2.14\end{array}$ & $\begin{array}{l}1.40 \\
1.01 \\
1.27 \\
0.83\end{array}$ & $\begin{array}{l}78.7 \\
49.3 \\
73.0 \\
38.8\end{array}$ & $\begin{array}{l}0.25-6.23 \\
0.67-4.98 \\
0.38-5.43 \\
0.93-3.81\end{array}$ & $\begin{array}{l}32.4 \\
37.3 \\
31.6 \\
38.9\end{array}$ \\
\hline 12 & $\begin{array}{l}\text { A } \\
\text { B } \\
\text { C } \\
\text { D }\end{array}$ & $\begin{array}{l}27 \\
28 \\
24 \\
27\end{array}$ & $\begin{array}{l}5.56 \\
5.57 \\
5.83 \\
5.37\end{array}$ & $\begin{array}{l}2.44 \\
2.91 \\
2.50 \\
3.24\end{array}$ & $\begin{array}{l}1.16 \\
1.16 \\
1.21 \\
1.13\end{array}$ & $\begin{array}{l}47.5 \\
39.9 \\
48.4 \\
34.9\end{array}$ & $\begin{array}{l}0.55-5.20 \\
1.55-7.08 \\
1.09-6.18 \\
1.76-6.00\end{array}$ & $\begin{array}{l}43.9 \\
52.2 \\
42.9 \\
60.3\end{array}$ \\
\hline 13 & $\begin{array}{l}\mathrm{A} \\
\mathrm{B} \\
\mathrm{C} \\
\mathrm{D}\end{array}$ & $\begin{array}{l}20 \\
20 \\
18 \\
20\end{array}$ & $\begin{array}{l}6.15 \\
6.15 \\
6.44 \\
6.15\end{array}$ & $\begin{array}{l}2.01 \\
2.60 \\
2.43 \\
2.96\end{array}$ & $\begin{array}{l}0.94 \\
1.06 \\
1.39 \\
1.49\end{array}$ & $\begin{array}{l}46.8 \\
40.8 \\
57.2 \\
50.3\end{array}$ & $\begin{array}{l}0.85-4.32 \\
1.37-5.25 \\
0.94-5.39 \\
1.52-7.65\end{array}$ & $\begin{array}{l}32.7 \\
42.3 \\
37.7 \\
48.1\end{array}$ \\
\hline 14 & $\begin{array}{l}\text { A } \\
\text { B } \\
\text { C } \\
\text { D }\end{array}$ & $\begin{array}{c}2 \\
1 \\
- \\
1\end{array}$ & $\begin{array}{c}3.50 \\
3.00 \\
- \\
3.00\end{array}$ & $\begin{array}{c}0.30 \\
1.02 \\
- \\
1.03\end{array}$ & $\begin{array}{c}0.06 \\
- \\
- \\
-\end{array}$ & $\begin{array}{c}20.0 \\
- \\
- \\
-\end{array}$ & $\begin{aligned} 0.26 & -0.34 \\
& - \\
& - \\
& -\end{aligned}$ & $\begin{array}{c}8.6 \\
34.0 \\
- \\
34.3\end{array}$ \\
\hline 15 & $\begin{array}{l}\text { A } \\
\text { B } \\
\text { C } \\
\text { D }\end{array}$ & $\begin{array}{l}21 \\
20 \\
18 \\
20\end{array}$ & $\begin{array}{l}7.67 \\
7.90 \\
8.22 \\
7.90\end{array}$ & $\begin{array}{l}2.12 \\
2.68 \\
2.25 \\
3.13\end{array}$ & $\begin{array}{l}1.39 \\
1.62 \\
1.38 \\
1.50\end{array}$ & $\begin{array}{l}65.6 \\
60.4 \\
61.3 \\
47.9\end{array}$ & $\begin{array}{l}0.70-5.73 \\
1.00-7.30 \\
1.08-4.78 \\
1.51-7.40\end{array}$ & $\begin{array}{l}27.6 \\
33.9 \\
27.4 \\
39.6\end{array}$ \\
\hline 16 & $\begin{array}{l}\text { A } \\
\text { B } \\
\text { C } \\
\text { D }\end{array}$ & $\begin{array}{l}3 \\
4 \\
7 \\
4\end{array}$ & $\begin{array}{r}10.33 \\
9.50 \\
9.00 \\
9.50\end{array}$ & $\begin{array}{l}2.31 \\
3.36 \\
2.87 \\
3.76\end{array}$ & $\begin{array}{l}1.72 \\
2.57 \\
1.38 \\
2.96\end{array}$ & $\begin{array}{l}74.5 \\
76.5 \\
48.1 \\
78.7\end{array}$ & $\begin{array}{l}1.27-4.30 \\
1.57-7.18 \\
1.42-4.90 \\
2.01-8.19\end{array}$ & $\begin{array}{l}22.4 \\
35.4 \\
31.9 \\
39.6\end{array}$ \\
\hline Total & $\begin{array}{l}\text { A } \\
\text { B } \\
\text { C } \\
\text { D }\end{array}$ & $\begin{array}{l}200 \\
193 \\
18 \\
195\end{array}$ & $\begin{array}{l}5.46 \\
5.48 \\
5.65 \\
5.46\end{array}$ & $\begin{array}{l}1.77 \\
2.30 \\
1.85 \\
2.44\end{array}$ & $\begin{array}{l}1.18 \\
1.18 \\
1: 18 \\
1.25\end{array}$ & $\begin{array}{l}66.7 \\
51.3 \\
63.8 \\
51.2\end{array}$ & $\begin{array}{l}0.16-6.23 \\
0.00-7.30 \\
0.19-6.18 \\
0.55-8.19\end{array}$ & $\begin{array}{l}32.4 \\
42.0 \\
32.7 \\
44.7\end{array}$ \\
\hline
\end{tabular}


Table 2 presents forward extrapolation ranges $\left(\rightarrow \mathbb{Z}_{0.05}\right.$ ) relative to the empirical daia ranges $\left(\mathbb{Z}_{E}\right)$. Mean values of extrapolation ranges for each $\mathbb{Z}_{E}$ are treated statistically with standard deviations, coefficients of variation, and variability ranges being given. To describe in detail the values studied, relative extrapolation ranges $\left(\rightarrow \mathbb{Z}_{W}\right)$ with respect to the model data ranges $\left(\mathbb{Z}_{M}\right)$ are given as well.

The results obtained for $\rightarrow \mathbb{Z}_{0.05}$ : values are rather low for the $\mathbb{Z}_{E}$ ranges: they exceed 4 years in a few cases only (the von Bertalanffy model for $\mathbb{Z}_{\mathbb{E}}=13$ as well as the binomial and von Bertalanffy equation for $\mathbb{Z}_{E}=15$ ). The overall mean $\rightarrow \mathbb{Z}_{0.05}$ values for the first three models exceed 2 years, while the $\rightarrow \mathbb{Z}_{0.05}$, value for the Ford-Walford model is slightly lower than $2 \mathrm{yr}$. The highest mean $\stackrel{0.05}{\rightarrow} \mathbb{Z}_{0.05}(2.43 \mathrm{yr})$ was found for the von Bertalanffy equation.

A relatively wide scatter of $\rightarrow \mathbb{Z}_{0.05}$, values is typical here. Coefficients of variation $(v)$, most reliable in this regard, exceed, in some cases, $100 \%$; the values of coefficients calculated for the entire set of data range between $68.7 \%$ (the Gompertz equation) and $89.9 \%$ (the Ford-Walford model). The wide scatter of results is evidenced also by variability ranges, the widest range $(0.19-12.00)$ being recorded in the case of the von Bertalanffy equation.

Relatively low values of $\rightarrow \mathbb{Z}_{0.05}$ largely result from the fact that most of them were calculated from small $\mathbb{Z}_{M}$ ranges which, as will be seen further on, affects considerably the extrapolation range. This is indirectly confirmed by values of $\mathbb{Z}_{W}$, calculated as per cent in relation to $\mathbb{Z}_{\mathrm{M}}$. The relative extrapolation ranges for different $\mathbb{Z}_{E}$ and various growth models fluctuate from 12.5 to $82.0 \%$, the mean values for the first three growth models considerably exceeding $40 \%$ (the highest value, $47.6 \%$, was found for the von Bertalanffy equation); it was only for the Ford.Walford model that the mean $\mathbb{Z}_{W}$ was $37.1 \%$.

Table 3 shows, in the same way as Table 2, absolute and relative are values of backward extrapolation. The absolute $\leftarrow \mathbb{Z}_{0.05}$ values slightly lower than those in the forward extrapolation, except for the Ford-Walford model where the mean backward extrapolation range is clearly higher than in the forward extrapolation. The remaining three growth models yield lower $\mathbb{Z}_{0.05}$ values in backward extrapolation, the difference being very small (0.13) when using the von Bertalanffy equation; the binomial and Gompertz equation used in forward and backward extrapolations produce differences amounting to 0.50 and 0.49 , respectively. The $\leftarrow \mathrm{z} 0.05$ values are less scattered than in forward extrapolation (coefficients of variation for the mean values ranged within 51.2-66.7\%); variability ranges were narrower, too (the widest range recorded, 0.55-8.19, concerned the Ford-Walford model).

The two tables discussed above contain also data which concern all the cases examined ("Total"). Although these results have been often referred to above, they should be treated as tentative only, due to an incomplete comparability of the partial results calculated for different $Z_{E}$ and $Z_{M}$ (see reservations in the beginning of "Results").

Due to noticeable differences between extrapolation ranges $\left(Z_{0.05}\right)$, both in the 
forward and backward extrapolation with the same growth model as well as when using different models, the significance of these differences was tested for with Student's $t$ test (confidence level of 0.95 ). The distribution of $\mathrm{Z}_{0.05}$ : values is assumed to approach normal.

Table 4 presents the differences studied as determined from the overall values ("Total" in Tables 2 and 3). The first part of the table contains differences emerging when using the same growth model for the forward and backward extrapolation. As seen from the table, it is only the von Bertalanffy equation that produces a statistically non-significant difference. The second part of the table presents differences in forward extrapolation

Table 4

Significance of differences between $\mathrm{Z}_{0.05}$ values as tested with Student's t test $(+=$ differences statistically significant; $-=$ differences statistically non-significant $)$

\begin{tabular}{|c|c|}
\hline Difference & Significance \\
\hline$(\rightarrow \mathrm{A})-(\leftarrow \mathrm{A})$ & + \\
$(\rightarrow \mathrm{B})-(\leftarrow \mathrm{B})$ & + \\
$(\rightarrow \mathrm{C})-(\leftarrow \mathrm{C})$ & + \\
$(\rightarrow \mathrm{D})-(\leftarrow \mathrm{D})$ & - \\
\hline$(\rightarrow \mathrm{A})-(\rightarrow \mathrm{B})$ & - \\
$(\rightarrow \mathrm{A})-(\rightarrow \mathrm{C})$ & - \\
$(\rightarrow \mathrm{A})-(\rightarrow \mathrm{D})$ & + \\
$(\rightarrow \mathrm{B})-(\rightarrow \mathrm{C})$ & + \\
$(\rightarrow \mathrm{B})-(\rightarrow \mathrm{D})$ & + \\
$(\rightarrow \mathrm{C})-(\rightarrow \mathrm{D})$ & - \\
\hline$(\leftarrow \mathrm{A})-(\leftarrow \mathrm{B})$ & + \\
$(\leftarrow \mathrm{A})-(\leftarrow \mathrm{C})$ & + \\
$(\leftarrow \mathrm{A})-(\leftarrow \mathrm{D})$ & - \\
$(\leftarrow \mathrm{B})-(\leftarrow \mathrm{C})$ & + \\
$(\leftarrow \mathrm{B})-(\leftarrow \mathrm{D})$ & + \\
$(\leftarrow \mathrm{C})-(\leftarrow \mathrm{D})$ & + \\
\hline
\end{tabular}

Note: the differences presented above,concern total results ('Total" in Tables 2 and 3)

when using different models (significance of differences was tested for in 6 possible combinations of pairs of the four growth models used). The differences were non-significant in most cases; significant differences were found between the von Bertalanffy equation and Ford-Walford model and between the Gompertz equation and Ford-Walford model. The third part of the table contains data, analogous to the second part, for the backward extrapolation. Most differences are statistically significant here; non-significant are the differences between the binomial and Gompertz equation, and between the von Bertalanffy equation and Ford-Walford model. 
Values of relative extrapolation ranges $\left(\mathrm{Z}_{\mathrm{W}}\right)$ in 5 size classes (from $<25 \%$ to $>100 \%$ ) relative to grow th models tested

\begin{tabular}{|c|c|c|c|c|c|c|c|c|c|c|c|c|}
\hline \multirow{3}{*}{ Model } & \multicolumn{12}{|c|}{$\rightarrow$} \\
\hline & \multicolumn{2}{|c|}{$<25$} & \multicolumn{2}{|c|}{$26-50$} & \multicolumn{2}{|c|}{$51-75$} & \multicolumn{2}{|c|}{$76-100$} & \multicolumn{2}{|c|}{$>100$} & \multicolumn{2}{|c|}{ Total } \\
\hline & $\mathrm{n}$ & $\%$ & $\mathrm{n}$ & $\%$ & $\mathrm{n}$ & $\%$ & $\mathrm{n}$ & $\%$ & $\mathrm{n}$ & $\%$ & $\mathrm{n}$ & $\%$ \\
\hline A & 67 & 34,7 & 62 & 32.1 & 24 & 12,4 & 15 & 7.8 & 25 & 13.0 & 193 & 100.0 \\
\hline B & 51 & 28.5 & 61 & 34.0 & 32 & 17,9 & 15 & 8.4 & 20 & 11.2 & 179 & 100.0 \\
\hline C & 54 & 27.6 & 81 & 41.3 & 29 & 14.8 & 18 & 9.2 & 14 & 7.1 & 196 & 100.0 \\
\hline D & 87 & 45.1 & 55 & 28.5 & 25 & 12.9 & 10 & 5.2 & 16 & 8.3 & 193 & 100.0 \\
\hline & & & & & & $\leftarrow$ & & & & & & \\
\hline A & 87 & 43.5 & 74 & 37.0 & 22 & 11.0 & 9 & 4.5 & 8 & 4.0 & 200 & 100.0 \\
\hline B & 46 & 23.8 & 78 & 40.5 & 40 & 20.7 & 16 & 8.3 & 13 & 6.7 & 193 & 100.0 \\
\hline $\mathrm{C}$ & 80 & 42.3 & 73 & 38.6 & 24 & 12.7 & 6 & 3.2 & 6 & 3.2 & 189 & 100.0 \\
\hline D & 38 & 19.5 & 84 & 43.0 & 45 & 23.1 & 13 & 6.7 & 15 & 7.7 & 195 & 100.0 \\
\hline
\end{tabular}


It is obvious that the above considerations cannot be directly transferred onto the detailed results. However, the varying scatter of the calculated results in different $Z_{M}$ ranges and various growth models allows to suppose that proportions of significant and nonsignificant differences are more or less the same. Thus it can be concluded that none of the models tested can be regarded as decidedly the best one in terms of its potential to extrapolate the results calculated.

Returning to the data presented in Table 3 it should be mentioned that the relative values of extrapolation ranges are lower for the first three models than in the forward extrapolation. Similarly to the absolute values $\left(Z_{0.05}\right)$, the differences between forward and backward extrapolations are much greater in the binomial and Gompertz equation than in the von Bertalanffy equation. On the other hand, the Ford-Walford model produces better results (higher $\mathbb{Z}_{\mathrm{W}}$ values) in backward than in forward extrapolation.
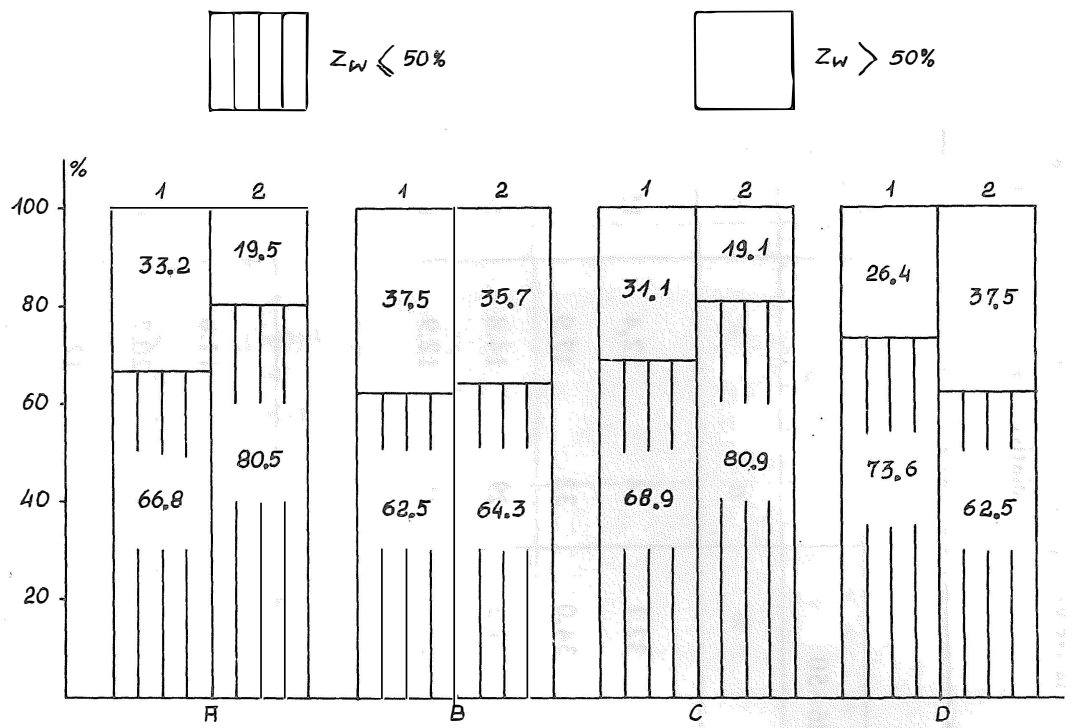

Fig. 3. Numerical proportions between relative extrapolation ranges $\left(\mathrm{Z}_{\mathrm{W}}\right)$ $\mathrm{A}, \mathrm{B}, \mathrm{C}$, and $\mathrm{D}$ as in Table 2; 1 = forward extrapolation; 2 = backward extrapolation

Table 5 contains results concerning relative extrapolation ranges. The calculated values are presented in 5 classes, from values lower than $25 \%$ to those exceeding $100 \%$. Fig. 3 shows the same values divided into two classes only: below and above 50\%. Both the table and the figure confirm the above considerations on the absolute values of $Z_{0.05}$ (Tables 2 and 3). The considerations are also confirmed by data in Table 6 presenting ratios between absolute and relative ranges of the forward and backward extrapolations, calculated for means of the entire set of data. The first three models produce ratios 
Values of rations $\frac{\rightarrow \mathrm{Z}_{0.05}}{\leftarrow \mathrm{Z}_{0.05}}$ and $\frac{\rightarrow \mathrm{Z}_{\mathrm{W}}}{\leftarrow \mathrm{Z}_{\mathrm{W}}}$ calculated from mean values

for entire set data, relative to growth model tested

\begin{tabular}{|c|c|c|}
\hline Model & $\frac{\rightarrow \mathrm{Z}_{0.06}}{\leftarrow \mathrm{Z}_{0.05}}$ & $\frac{\rightarrow \mathrm{Z}_{\mathrm{W}}}{\leftarrow \mathrm{Z}_{\mathrm{W}}}$ \\
\hline $\mathrm{A}$ & 1.28 & 1.39 \\
$\mathrm{~B}$ & 1.06 & 1.13 \\
$\mathrm{C}$ & 1.26 & 1.39 \\
$\mathrm{D}$ & 0.79 & 0.83 \\
\hline
\end{tabular}

greater than 1 (which shows that the forward wxtrapolation ranges are higher than those of backward extrapolation), the ratio lower than 1 being found for the Ford-Walford model only. The von Bertalanffy equation gave a ratio closest to unity (the smallest difference between the forward and backward extrapolation ranges).

Going back, once more, to data in Tables 2 and 3. it should be noted that absolute values of $\mathrm{Z}_{0.05}$ show a weak tendency to increase with increasing values of $\mathrm{Z}_{\mathrm{E}}$. Two marked deviations from this tendency for $\mathrm{Z}_{\mathrm{E}}=14$ and 16 years are observed, but both cases concern a single species each time (Huso huso and Acipenser stellatus, respectively) and cannot be therefore regarded as fully representative.

Table 7 presenis parameters of linear relationships between the extrapolation and empirical ranges $\left(Z_{0.05}=a+b Z_{E}\right)$. For the absolute values of extrapolation ranges, direction coefficients(b) were always positive, both in the forward and backward extrapolation, which proves a direct relationszip between $\mathrm{Z}_{0.05}$ and $\mathrm{Z}_{\mathrm{E}}$. On the other hand, negative direction coefficients were coefficients were found in 7 cases of relationships between the relative extrapolation range and empirical range $\left(Z_{W}=a+\right.$ $\mathrm{bZ} \mathrm{Z}_{\mathrm{E}}$ ), which demonstrates an inverse relationship between the two ranges (decreasing $\mathrm{Z}_{\mathrm{W}}$ with increasing $Z_{E}$ ). A positive value of $b$ was recorded only when $u$ sing the Gompertz model for backward extrapolation.

Low direction coefficients in both types of the relationship described above demonstrate a relatively weak increasing $\left(\mathrm{Z}_{0.05}\right)$ and decreasing $\left(\mathrm{Z}_{\mathrm{W}}\right)$ tendency with increasing $Z_{E}$. The absolute values of the direction coefficient show that, on the average, when $\mathrm{Z}_{\mathrm{E}}$ increased by $1 \mathrm{yr}, \mathrm{Z}_{0.05}$ increased by less than $0.1 \mathrm{yr}$ in 4 cases, and in the remaining four $Z_{0.05}$ increased by $0.1-0.2 \mathrm{yr}$. Similarly weak is adecreasing tendency in $Z_{W}$ (a 1 yr increase in $Z_{E}$ in accompanied, on the average, by a less than $1 \%$ decrease in $\mathrm{Z}_{\mathrm{W}}$ in four cases, by a slight increase above $1 \%$ in 3 cases, and by an increase of slightly more than $0.5 \%$ in the eighth case). 
Parameters of linear relationships $\mathrm{Z}_{0.05}=\mathrm{a}+\mathrm{bZ} \mathrm{E}_{\mathrm{W}}$ and $\mathrm{Z}_{\mathrm{W}}=\mathrm{a}+\mathrm{bZ} \mathrm{E}_{\mathrm{E}}$ in growth models tested

\begin{tabular}{|c|c|c|c|c|c|c|c|c|}
\hline \multirow{3}{*}{ Model } & \multicolumn{4}{|c|}{$Z_{0.05}=a+b Z_{E}$} & \multicolumn{4}{|c|}{$Z_{W}=a+b Z_{E}$} \\
\hline & \multicolumn{2}{|c|}{$\rightarrow$} & \multicolumn{2}{|c|}{$\leftarrow$} & \multicolumn{2}{|c|}{$\rightarrow$} & \multicolumn{2}{|c|}{$\leftarrow$} \\
\hline & $\mathrm{a}$ & $\mathrm{b}$ & $\mathrm{a}$ & $\mathrm{b}$ & $\mathrm{a}$ & $\mathrm{b}$ & $\mathrm{a}$ & $\mathrm{b}$ \\
\hline A & 1.3450 & 0.0850 & 0.8470 & 0.0730 & 50.2980 & -0.3680 & 40.8720 & -1.0020 \\
\hline B & 1.2490 & 0.1110 & 1.1740 & 0.0960 & 57.7180 & -0.8280 & 53.8030 & -1.0930 \\
\hline $\mathrm{C}$ & 1.1480 & 0.1020 & -0.1329 & 0.1853 & 52.8440 & -0.8140 & 25.8161 & 0.5742 \\
\hline D & 1.3450 & 0.0650 & 0.6230 & 0.1570 & 53.3010 & -1.1210 & 45.7930 & -0.2130 \\
\hline
\end{tabular}

Nota: the coefficients were calculated from values listed in Tables 2 and 3 under $Z_{E}, Z_{0.05}(\bar{x})$, and $Z_{W}$ 
As mentioned in "Materials and methods", growth models for various ranges of data $\left(Z_{M}\right)$ were calculated for each species. Depending on the empirical data range $\left(Z_{E}\right)$, from 2 to 10 versions of each model were calculated for each species. Such procedure of calculations allowed to find out how the extrapolation rangesdepends on the empirical range of data used in models. Linear relationships of the type $Z_{0.05}=a+b Z_{M}$ were calculated for the fish species studied. Table 8 presents mean direction coefficients (b) for the relationships, and elements of their statistical characterisation.

The data in Table 8 show that the $Z_{0.05}$. vs. $Z_{M}$ relationship was not determined for all the 50 species. When a given growth model calculated for the lowest possible $Z_{M}$ allowed the maximum, theoretically possible, extrapolation (for example, at $Z_{E}=10$ a model calculated for $\mathrm{Z}_{\mathrm{M}}=3$ allowed to extrapolate within $\mathrm{Z}_{0.05}=7$ ) and when an increase in $\mathrm{Z}_{\mathrm{M}}$ resulted in $\mathrm{Z}_{0.05}$ values reaching the upper limit of $\mathrm{Z}_{\mathrm{E}}$ (for example, at

Table 8

Statistical characteristics of mean direction coefficients (b) in $\mathrm{Z}_{0.05}=\mathrm{a}+\mathrm{bZ} \mathrm{M}_{\mathrm{M}}$ in growth models tested

\begin{tabular}{|l|l|l|l|l|l|}
\hline Model & $\mathrm{n}$ & $\overline{\mathrm{x}}$ & $\sigma$ & $\mathrm{v}$ & Variability range \\
\hline \multicolumn{6}{|c|}{$\rightarrow$} \\
\hline $\mathrm{A}$ & 45 & 0.60 & 1.29 & 215.0 & $-0.86-6.00$ \\
$\mathrm{~B}$ & 39 & 0.51 & 1.48 & 290.2 & $-0.75-6.88$ \\
$\mathrm{C}$ & 45 & 0.74 & 1.09 & 147.3 & $-0.51-5.44$ \\
$\mathrm{D}$ & 43 & 0.74 & 1.70 & 229.7 & $-0.93-6.73$ \\
\hline \multicolumn{7}{|c|}{$\leftarrow$} \\
A & 46 & -0.15 & 0.48 & 320.0 & $-1.28-0.98$ \\
B & 44 & -0.21 & 0.47 & 223.8 & $-1.02-1.28$ \\
C & 45 & -0.06 & 0.39 & 650.0 & $-1.12-0.95$ \\
D & 45 & -0.05 & 0.54 & 360.0 & $-0.98-1.78$ \\
\hline
\end{tabular}

$\mathrm{Z}_{\mathrm{M}}=4, \mathrm{Z}_{0.05}=6$; at $\mathrm{Z}_{\mathrm{M}}=5, \mathrm{Z}_{0.05}=5$, etc.), the table includes the first result only, obtained for the smallest possible range of $Z_{M}$. An assumption was made that, in such cases, a decrease in $Z_{0.05}$ with increasing $Z_{M}$. is obviously caused by the lack of possibility to compare the calculated and empirical data, and not by a true decrease in a range of possible extrapolation. It was impossible, with only a single $Z_{0.05}$ value for a species, to determine a relationship between $\mathrm{Z}_{0.05}$ and $\mathrm{Z}_{\mathrm{M}}$. This is also why the number of results obtained for the extrapolation range is lower than the number of growth models calculated (sums of $\rightarrow \mathrm{Z}_{0.05}$ and $\leftarrow \mathrm{Z}_{0.05}$, values were 761 and 777 , respectively). 
Table 9

Numerical proportions between positive and negative values of direction coefficients $(b)$ in $Z_{0.05}=a+b Z_{M}$ in forward and backward extrapolations with growth models used

\begin{tabular}{|c|c|c|c|c|c|c|c|c|c|c|}
\hline \multirow{3}{*}{ Model } & \multicolumn{6}{|c|}{$\rightarrow$} & \multicolumn{4}{|c|}{$\leftarrow$} \\
\hline & \multicolumn{2}{|c|}{$>0$} & \multicolumn{2}{|c|}{$<0$} & \multicolumn{2}{|c|}{$=0$} & \multicolumn{2}{|c|}{$>0$} & \multicolumn{2}{|c|}{$<0$} \\
\hline & $\mathrm{n}$ & $\%$ & $\mathrm{n}$ & $\%$ & $\mathrm{n}$ & $\%$ & $\mathrm{n}$ & $\%$ & $\mathrm{n}$ & $\%$ \\
\hline A & 31 & 68.9 & 14 & 31.1 & - & - & 20 & 43.5 & 26 & 56,5 \\
\hline B & 20 & 51.3 & 18 & 46.1 & 1 & 2.6 & 12 & 27.3 & 32 & 72.7 \\
\hline C & 35 & 77.8 & 10 & 22.2 & - & - & 21 & 46.7 & 24 & 53.3 \\
\hline D & 24 & 55.8 & 19 & 44.2 & - & - & 15 & 33.3 & 30 & 66.7 \\
\hline
\end{tabular}


Similar was the procedure in those cases when a model calculated for a $\mathbb{Z}_{\mathbb{M}}$ range (not necessarily the smallest one) allowed to extrapolate up to the upper limit of $\mathbb{Z}_{E}$, and a further increase in $\mathbb{Z}_{M}$ always resulted in an extrapolation range reaching theslimit of the empirical data. In such cases, only the results obtained from $\mathbb{Z}_{\mathrm{M}}$ ranges before extrapolation to this limit was possible were considered.

The data in Table 8 show that mean values of direction coefficients were positive for the four growth models applied, which demonstrates a direct relationship between $\mathbb{Z}_{0.05}$ and $Z_{M}$ (the larger the data range for growth models, the larger - usually - the extrapolation range). It should be noted that in some cases the relationship was inverse (the direction coefficient was then negative, which is reflected in data on the coefficient of variation). However, in most cases of forward extrapolation, the $\mathbb{Z}_{0.05}$ vs. $\mathbb{Z}_{M}$ relationship was direct, although, when using the von Bertalanffy model a difference between cases with direct and inverse relationships was very small (Table 9).

Apart from the proportion between positive and negative coefficients (see Table 9), positive mean values of direction coefficients in forward extrapolation resulted also from the fact than the absolute values of positive coefficients were, as a rule, much higher than those of negative coefficients. This is evidenced to some extent by mean values and variability ranges given in Table 8 .

Furthermore, mean values of direction coefficients show the $\rightarrow \mathbb{Z}_{0.05}$ vs. $\mathbb{Z}_{M}$ values demonstrate that, with $Z_{M}$ increasing by $1 \mathrm{yr}$, the extrapolation range increases by, on the average, 0.51 (the von Bertalanffy equation) to 0.74 (the Gompertz and Ford-Walford models). The reverse was true with respect to the backward extrapolation (the second part of Table 8): mean direction coefficients of the $\mathbb{Z}_{0.05}$ vs. $\mathbb{Z}_{M}$ relationship were negative in all four growth models. It should be mentioned, however, that absolute values and variability ranges of the coefficients were much lower here than in the forward extrapolation. The data in Table 9 demonstrate that the von Bertalanffy equation applied to the backward extrapolation provided the best-defined numerical proportions of direct and inverse relationships between $\mathbb{Z}_{0.05}$ and $\mathbb{Z}_{M}$, the Gompertz model producing proportions which were levelled off most (the reverse situation was found in the forward extrapolation).

One should emphasise a wide scatter of the direction coefficients discussed. In the forward extrapolation, the coefficients of variation range within 147.3-290.2\%, still higher coefficients being found in the backward extrapolation (except for the von Bertalanffy equation), up to $650 \%$ when using,the Gompertz model.

\section{DISCUSSION}

Due to the absence of similar studies in the literature it was impossible to provided the reader with a traditional, for a "Discussion" chapter, comparison between results 
presented here and those obtained by other authors. In view of the fact that the tables contain mean values only, the discussion below comments on certain important observations emerging from the detailed data not considered in tables.

The first fact, and a very conspicuous one, is an immense variability of extrapolation ranges calculated for the same fish species with different growth models. In the forward extrapolation, identical extrapolation ranges were obtained in 5 out of 761 cases of using the four growth models: at $\mathrm{Z}_{\mathrm{M}}=3$ for Oncorhynchus keta; at $\mathrm{Z}_{\mathrm{M}}=4$ for Scorpaena porcus; at $\mathrm{Z}_{\mathrm{M}}=5$ for Aspius aspius; at $\mathrm{Z}_{\mathrm{M}}=4$ for Parabramis pekinensis; and at $\mathrm{Z}_{\mathrm{M}}=7$ for Coregonus lavaretus widegreni. Differences, usually rather large, were observed in all the remaining cases. Extremely large differences were found for Ctenopharyngodon idella $\left(Z_{M}=3\right)$ with the extrapolation range varying from 0.68 (the Gompertz model) to 10.0 (the von Bertalanffy and Ford-Walford models) and for Coregonus lavaretus baikalensis with still larger variation: from 0.34 (the Ford-Walford model) to 12.00 (the von Bertalanffy equation). No identical, for all four models, extrapolation ranges were found in the backward extrapolation; the relatively smallest differences were recorded for Sardinops sagax: at $Z_{M}=3, Z_{0.05}$ varied from 2.02 in the binomial to 2.08 in the remaining three models. The largest differences were, however, smaller than in the forward extrapolation (for $A$ theresthes evermanni, at $Z_{M}=4 \leftarrow Z_{0.05}$ : varied from 0.76 in the binomial to 7.40 in the Ford-Walford model). Mean extrapolation ranges given in Tables 2 and 3 differ much less, which results from the fact that, when looking at the detailed data for various fish species, no clear prevalence of some of the models in terms of their extrapolation potential could be detected. Frequently, the largest extrapolation ranges at various $Z_{M}^{\prime}$ 's of the same species were obtained with different models (for example, in the backward extrapolation for Leuciscus schmidtii at $Z_{M}=4$ the largest extrapolation range was obtained with the binomial; at $Z_{M}=5$ with the Ford-Walford model; and with the von Bertalanffy equation at $\mathrm{Z}_{\mathrm{M}}=6$, etc.).

The next problem in need of a critical appraisal concerns the wide scatter of calculated extrapolation ranges (in most cases, the coefficient of variation exceeded 50\%; some cases of the forward extrapolation produced coefficients higner than $100 \%$ ). Such a wide scatter may cast some doubt on utility of the mean values reported in Tables 2 and 3. However, a thorough analysis of the detailed data for various fish species revealed that it is relatively easy to check if a given model can be extrapolated over a range wide enough. Namely, the growth equation parameters determined from the smallest and the largest $\mathrm{Z}_{\mathrm{M}}^{\prime}$ 's differed only slightly in all the cases allowing the longest, theoretically possible, extrapolation. This principle is additionally confirmed by the cases when a model, calculated from the smallest possible $Z_{M}$ (3 years, as a rule) allowed a relatively short extrapolation, while models calculated for the subsequent $Z_{M}^{\prime}$ 's produced $Z_{0.05}$ values reaching the upper limit of $Z_{E}$. In such cases, parameters of the first model differed clearly from those in the remaining ones which, in turn, differed only slightly among one another. Thus, in order to check if a given model allows appropriate extrapolation in any concrete case, it should be calculated in two versions: from the smallest possible $Z_{M}$ 
( 3 years if possible) and from the entire $Z_{E}$ (terminal, not completely representative data may be rejected, if necessary). If the parameters of the two versions differ slightly only, extrapolation within $50 \%$ of $\mathrm{Z}_{\mathrm{M}}$ is, most probably, possible (the larger of the two ranges may be adopted here as $Z_{M}$, which is justified by small differences between the parameters). This procedure is supported by the values of $\mathrm{Z}_{\mathrm{W}}$ calculated for the entire material analysed and varying from more than 30 to more than $40 \%$ (cf. Tables 2 and 3), the values incorporating also numerous small extrapolation ranges (as seen from Fig. 3 , $\mathrm{Z}_{\mathrm{W}}$ values lower than $50 \%$ were decidedly more numerous in all four growth models tested).

Finally, relationships between the extrapolation range and $\mathrm{Z}_{\mathrm{E}}$ and $\mathrm{Z}_{\mathrm{M}}$ deserve a comment. Parameters of the first relationship (Table 7) indicate that $Z_{0.05}$ values increase only slightly (and $Z_{W}$ values decrease) with increasing $Z_{E}$. In other words, the range of empirical data has a relatively small effect on the extrapolation range, both in the forward and backward extrapolation and in all growth models tested.

The relationship between the extrapolation range and $Z_{M}$ is different. In the forward extrapolation, mean direction coefficients of $Z_{M}$ of $Z_{0.05}=a+b Z_{M}$ point to a clear-cut relationship between the two ranges (Table 8). However, one should consider the very wide scattee of the results, making it difficult to assess their applicability and reliability. The relationship is much less distinct in the backward extrapolation (absolute values of the direction coefficients are only slightly higher than the corresponding values in $Z_{0.05}=a+b Z_{E}$ ) and it is inverse. The very wide scatter here (much wider, except for the von Bertalanffy equation, than in the forward extrapolation), too, makes an unequivocal assessment of the results difficult.

With all the reservations emerging from a wide scatter of values, the relationships discussed may suggest that the growth models (particularly the Gompertz and Ford-Walford ones) in the forward extrapolation should be calculated from possibly wide $\mathrm{Z}_{\mathrm{M}}^{\prime}$ 's. The magnitue of $\mathrm{Z}_{\mathrm{M}}$ matters much less in the backward extrapolation; it is only with respect to the von Bertalanffy equation that the results obtained appear to suggest a possibly small $\mathrm{Z}_{\mathrm{M}}$ (the highest absolute direction coefficient in the inverse relationship between $\leftarrow Z_{0.05}$, and $Z_{M}$ ). In practice, however, if the extreme values of the variability range are considered, the magnitude of $Z_{M}$ in the backward extrapolation has basically no effect on the extrapolation range obtained.

\section{CONCLUSIONS}

1) Extrapolation of fish length growth beyond the range od empirical data is possible over about 2 years (absolute values) or over about $40 \%$ of the range of data used in a given growth model. These are mean values for all the cases tested.

2) Due to a wide scatter of detailed data, it is necessary to find out whether a case on hand can be extrapolated and over what range. In all cases where a model calculated 
from the minimum $\mathrm{Z}_{\mathrm{M}}$ allowed the maximum, theoretically possible, extrapolation (over the entire $\mathbb{Z}_{E}$ ), parameters of various of the model calculated for varying $\mathbb{Z}_{M}$ differed only slightly among themselves. In such cases, extrapolation is possible over a range much wider than that stated in 1.

3) A considerable variability in extrapolation ranges obtained with various growth models for the same species was observed.

4) In the forward extrapolation, a distinct direct relationship between the extrapolation range obtained $\left(\rightarrow \mathrm{Z}_{0.05}\right)$ and $\mathrm{Z}_{\mathrm{M}}$ was found. The remaining relationships analysed $\left(\leftarrow Z_{0.05}\right.$ vs. $Z_{M} ; \rightarrow Z_{0.05}$ vs. $Z_{E} ; \rightarrow Z_{W}$ vs. $Z_{E} ; \leftarrow Z_{0.05}$ vs. $Z_{E} ;$ and $\leftarrow Z_{W}$ vs. $\left.Z_{E}\right)$ were much less distinct (low direction coefficients of equations describing the relationships).

\section{REFERENCES}

Anon., 1949: Promyslovyje ryby SSR. Piscepromizdat, Moskwa. (in Russian)

Cięglewicz W., Draganik B., 1969: Charakterystyka wzrostu czarniaka (Pollachius virens L.) z Morza Norweskiego i Morza Północnego. [Characteristic of growth of coalfish (Pollachius virens L.) from the Norwegian Sea and the North Sea]. Prace MIR, 15A, 133-152.

Krzykawski S., 1976: A characteristics of growth of Greenland halibut, Reinhardtius hippoglossoides (Walbaum), from the North Atlantic. Acta Ichth. et'Piscato, BI, 2: 79-102.

Nikolski G.W., 1956: Ryby bassejna Amura. Izd. A.N. SSR, Moskwa. (in Russian)

Svetovidov A.N., 1964: Ryby Cernogo Moria. Izd。 "Nauka", Moskwa-Leningrad. (in Russian)

Szypuła Jo, 1980: Assessment of the effect of environmental factors on fish growth using growth coefficients calculated from mathematical description of fish growth by means of polynomials. Acta Ichth. et Piscat., X, 1:3-24.

\section{Jerzy Szypuła}

\section{PRÓBA ZASTOSOWANIA RÓZ̊NYCH MODELI MATEMATYCZNYCH DO EKSTRAPOLACJI TEMPA WZROSTU DEUGOŚĆI RYB POZA ZAKRES DANYCH EMPIRYCZNYCH}

\section{STRESZCZENIE}

W niniejszej pracy podjęto próbę określenia moźliwości ekstrapolacji matematycznej charakterystyki wzrostu ryb, obliczonej przy pomocy 4 najczęściej stosowanych modeli wzrostu długości (wielomian 2 stopnia, równianie von Bertalanffy'ego, równanie Gompertza, formuła Forda-Walforda), poza zakresem dany ch empiry czny ch. Przyjęta metoda polegała na obliczaniu modelu z części dany ch empiry czny ch i porównywaniu wy ników ekstrapolowany ch $z$ wynikami empiry cznymi nie branymi pod uwagę przy obliczaniu modelu. Przyjęto, że wyniki ekstrapolowane są wystarczająco dokładne, jeżeli różnica $\mathrm{w}$ porównaniu $\mathrm{z}$ odpowiednimi danymi empiry cznymi nie przekracza 5\%. Przeprowadzano ekstrapolację „,do przodu" (obliczanie modelu z pierwszy ch lat ży cia; porównywanie dany ch ekstrapolowanych $z$ empirycznymi w dalszych latach) oraz ,do ty łu” (model z końcowych lat; porównywanie w początkowy ch latach ży cia).

Poddano analizie pod względem możliwości ekstrapolacji wzrost 50 gatunków ryb. Ponieważ dla każdego gatunku - zależnie od zakresu dany ch wyjściowy ch - obliczano po kilka (od 2 do 10) wersji każdego z przyjęty ch modeli wzrostu (dla różnych zakresów danych), ogółem obliczono 926 modeli 
wzrostu przy ekstrapolacji „,do przodu” oraz 798 modeli przy ekstrapolacji ,,do ty łu”.

Zaobserwowano duże zróżnicowanie wyników u różny ch gatunków, dla różny ch zakresów dany ch i dla różnych modeli wzrostu. Wyniki ogólne - dla wszystkich zbadanych gatunków - wskazują na możliw ość ekstrapolacji w zakresie około 2 lat lub - jeżeli chodzi o wartości względne - w zakresie około $40 \%$ wielkości zakresu danych, użyty ch do obliczania konkretnego modelu. W konkretnych przypadkach zakres możliwej ekstrapolacji może być znacznie większy (w przypadkach, w których zakres ekstrapolacji by $ł$ maksymalny - do górnej granicy $\mathrm{Z}_{\mathrm{E}}$ - parametry wersji modelu, obliczony ch dla kolejnych zakresów $\mathrm{Z}_{\mathrm{M}}$ różniły się od siebie $\mathrm{w}$ minimalnym stopniu). Stwierdzono istnienie prostych zależności pomiędzy zakresem ekstrapolacji $\mathrm{Z}_{0.05}$ a zakresem danych wyjściowych $\mathrm{Z}_{\mathrm{E}}$ (w obu kierunkach) oraz zakresem ekstrapolacji ,do przodu" ( $\left.\rightarrow \mathrm{Z}_{0.05}\right)$ a zakresem dany ch uży ty ch do obliczania modelu $\left(Z_{M}\right)$ - ta ostatnia zależność zaznaczała się o wiele wyraźniej. Natomiast pomiędzy $\leftarrow \mathrm{Z}_{0.05}$ a $\mathrm{Z}_{\mathrm{M}}$ istnieje dość słabo zaznaczona zależność odwrotna.

Author's address:

Received: 87.02.02.

Doc. dr hab. Jerzy Szy puła

Insty tut Ich tiologii

ul. Kazimierza Królewicza 4

71-550 Szcze cin

Polska (Poland) 